\title{
Physical evaluation, morphological and identification of seminal proteins in Santa Ines sheep
}

\author{
Avaliação física, morfológica e identificação de proteínas seminais em ovinos da raça \\ Santa Inês
}

\author{
OLIVEIRA, Marilza Assunção de ${ }^{1}$; OLIVEIRA, Roseane Pinto Martins de ${ }^{1 *}$; LIMA, \\ Ana Rita de ${ }^{2}$; ANDRADE, Edmar Vaz de ${ }^{3}$; ABREU, Jan Sidarta Lima de ${ }^{4}$; OLIVEIRA, \\ Franklyn Ferreira de
}

\footnotetext{
${ }^{1}$ Universidade Federal do Amazonas, Faculdade de Ciências Agrárias, Laboratório de Anatomia e Fisiologia Animal, Manaus, Amazonas, Brasil.

${ }^{2}$ Universidade Federal Rural da Amazônia, Instituto de Saúde e Produção Animal, Laboratório de Pesquisa Morfológica Animal, Belém, Pará, Brasil.

${ }^{3}$ Universidade Federal do Amazonas, Laboratório de Proteômica, Manaus, Amazonas, Brasil.

${ }^{4}$ Zootecnista, Autônomo, Manaus, Amazonas, Brasil.

${ }^{5}$ Médico veterinário, Autônomo, FR Comércio e Serviços Veterinários LTDA, Manaus, Amazonas, Brasil.

*Endereço para correspondência: roseanepmoliveira@gmail.com
}

\section{SUMMARY}

This study aimed to identify proteins in the seminal plasma associated with fertility in sheep of Santa Inês in Manaus, AM, using twodimensional electrophoresis techniques associated with mass spectrometry. Semen samples from eight adult sheep were collected by removing an aliquot for the physical and morphological assessments of semen and seminal plasma was subjected to SDS-PAGE profile and two-dimensional electrophoresis. Gels were stained with colloidal Coomassie, scanned and analyzed using ImageMaster 2D Platinum software, version 6.0. The selected individual spots were cut from the master gel, digested with trypsin and subjected to identification by mass spectrometry (MALDITof / Tof). Of the 108 spots detected in the gel, it selected 10 differential spots (based on the distribution thereof in the bidimensional gel and pre-analysis of the 2D ImageMaster Platinum Software) identifying 03 proteins: clusterin, a protein 14-3-3 zeta chain and Ram Seminal versicles $22 \mathrm{kDa}$ Protein. The identity of these proteins implies that the components of seminal plasma participate in physiological processes involved in sperm protection, motility and sperm capacitation, all associated with fertility. These proteins need to be better studied to see whether the same could be used as molecular markers of fertility as they were also found in other studies conducted with sheep Santa Ines.

Keywords: fertility, seminal plasma, twodimensional electrophoresis

\section{RESUMO}

Este estudo teve como objetivo identificar proteínas do plasma seminal associadas à fertilidade em ovinos da raça Santa Inês em Manaus, AM, utilizando técnicas de eletroforese bidimensional associadas à espectrometria de massa. Amostras de sêmen de oito carneiros adultos foram coletadas, retirando-se uma alíquota para as avaliações físicas $\mathrm{e}$ morfológicas do sêmen, e o plasma seminal foi submetido ao perfil SDS-PAGE e à eletroforese bidimensional. Os géis foram corados com Coomassie coloidal, digitalizados e analisados no aplicativo ImageMaster 2D Platinum, versão 6.0. Os spots selecionados foram cortados individualmente do gel mestre, digeridos com tripsina e submetidos à identificação por espectrometria de massa (MALDI-Tof/Tof). Dos 108 spots detectados no gel, selecionou-se 10 spots diferenciais (com base na distribuição dos mesmos no gel bidimensional e com a pré- 
análise destes no ImageMaster 2D Platinum Software), identificando-se 03 proteínas: a clusterina, a 14-3-3 protein zeta chain e a Ram Seminal Versicles $22 \mathrm{kDa}$ Protein. A identidade dessas proteínas infere que os componentes do plasma seminal participam de processos físiológicos ligados à proteção do espermatozoide, sua motilidade e capacitação espermática, todos associados à fertilidade. Essas proteínas precisam ser melhor estudadas para verificar se as mesmas poderiam ser utilizadas como marcadores moleculares de fertilidade, já que também foram encontradas em outros trabalhos realizados com ovinos da raça Santa Inês.

Palavras-chave: fertilidade, plasma seminal, eletroforese bidimensional

\section{INTRODUCTION}

Within the criterion used to search trustworthy indicators of the animals reproductive potential are: the sexual behavior, the semen parameters, among others (SOUZA et al., 2012). However, these evaluations define some minimum criterion to the selection and utilization of the breeding (REGO, 2010). However, if associated to the biochemical analysis, these could help to identify the fertility potential differences important among the selected animals (JOBIM et al., 2009).

The sheep seminal plasma acts on spermatic function and in the fertilization (CAVALCANTE et al., 2013). Moura et al. (2007) observed a relation between the proteins expression in the fluid of the reproductive tract and the breeding fertility, noting that there is evidence of significant associations between semen protein expression and male fertility evaluated in vivo and in vitro. These proteins may be candidates for molecular markers of fertility (KILLIAN et al., 1993, MOURA et al., 2007).
Souza et al. (2012) identified protein groups of the seminal plasma which play important roles in the reproductive physiology, taking part in the spermatic capacity, formation of the spermatic reservoir in the oviduct and spermatozoon- oocyte interaction in Santa Ines breed sheep.

In the search for better efficiency in fertility, beyond the parameters already known (breeding soundness examination, morphological and physiological characteristics of semen, etc.), but does not predict fertility at $100 \%$, there is a need to study other factors affecting same as, for example, the use of fluorescent probes in sperm assessment (by flow cytometry) and the evaluation of seminal plasma proteins. In seeking possible fertility indicators, the study of seminal plasma proteins which aims to seek interactions exist between these compounds and the sperm from ejaculation to fertilization (VALLE, 2012).

The secreted proteins in the male reproductive tract fluids, in particular seminal plasma, are associated with many aspects of reproductive function in ruminants (KILLIAN et al., 1993; BELLIN et al, 1998; SPROTT et al., 2000; MOURA et al., 2006a). The study of these proteins may contribute to a better understanding of the physiological processes related to fertility.

Thus, the current research has the objective to identify seminal plasma proteins associated to fertility in Santa Ines breed sheep, observing if there is a relation between the proteins and the semen physical characteristics and the spermatozoons morphology. 


\section{MATERIAL AND METHODS}

It was collected the semen from December 2014 to May 2015, using the synthetic vagina, of eight Santa Ines breedings belonging to S. Pedro farmer, located in Manaus city, at AM-010 Highway, $\mathrm{Km} 30,60^{\circ}$ west longitude, 3rd 08" south latitude, distant 1,700 Km straight coastline with altitude $92.9 \mathrm{~m}$ (HEYER, 1997), it features hot and humid tropical climate characteristics, with annual rainfall of $2,286 \mathrm{~mm}$ and average temperature between 27 to $29^{\circ} \mathrm{C}$ (INMET, 2006), at the age of three, weight and scrotal circumference of 80 $\pm 1,2 \mathrm{~kg} ; 30,04 \pm 1,49 \mathrm{~cm}$, respectively, under uniform conditions of management and nutrition, raised in semi- intensive system in Brachiaria humidicula pasture where it was carried out the physical evaluations (semen volume, semen aspect, turbulence, progressive motility, spermatic vigor), morphological (big and small defects), according to CBRA (1998) and moleculars (profile SDS-PAGE and two-dimensional). A $1,5 \mathrm{~mL}$ semen aliquot was centrifuged in $2.500 \mathrm{rpm}$ during 10 minutes to obtain seminal plasma, which was stowed in $2 \mathrm{~mL}$ microtubes and preserved in $20^{\circ} \mathrm{C}$ to subsequent analysis in laboratory. The animal which presented the best performance in all evaluations was chosen to molecular description by twodimensional electrophoresis, followed by mass spectrometry, identification and proteins description.

In order to quantify the semen plasma proteins it was used the 2-D Quant Kit (GE Healthcare) through the general formula $y=0,008 x-0,866 \quad\left(R^{2}=0,993\right)$, previously prepared, according to all established criteria to the kit. To analyze the extracted proteins quality and it was also carried out their SDS-PAGE. The gel was scanned using Lab Scam 5.0.

In the two-dimensional electrophoresis, the proteins sample were dissolved in a rehydration solution ( $1 \%$ of ampholyte (IPG Buffer $\mathrm{pH} 3-11$ ), both from GE Healthcare. A volume corresponding to $400 \mu \mathrm{g}$ proteins was applied to a $13 \mathrm{~cm}$ Immobiline Dry Strip (GE Healthcare, $\mathrm{pH} 3-11 \mathrm{NL}$ ), rehydrated during $10 \mathrm{~h}$ and e submitted to an isoelectric focusing during $12 \mathrm{~h}$ in EttanIPGphor II (Amershan Bioscience) in $20^{\circ} \mathrm{C}$ with a limit tension of $50 \mathrm{~mA} /$ strip, in the following steps: 1. $150 \mathrm{~V} / 2 \mathrm{~h} ; 2.300$ $\mathrm{V} / 2 \mathrm{~h} ; 3.1 .000 \mathrm{~V} / 4 \mathrm{~h}$ (gradient); 4. 8.000 $\mathrm{V} / 2 \mathrm{~h}$ (gradient); 5. $8.000 \mathrm{~V} / 2 \mathrm{~h}$. After focusing, the strips were balanced in an equilibrium solution I (urea 6M, SDS $2 \%$, glycerol $29,3 \%$, Tris- $\mathrm{HCl} 1,5 \mathrm{M} \mathrm{pH}$ 8,8 and DTT $0,5 \%$ ) subsequently alquylated in an equilibrium solution II (urea 6M, SDS 2\%, glycerol 29,3\%, Tris- $\mathrm{HCl} \quad 1,5 \mathrm{M} \quad \mathrm{pH} \quad 8,8$ and iodoacetamide 2,5\%), submitted right after to the separation by molecular mass in SDS-PAGE (polyacrilamide gel $12 \%$ ). To analyze the proteomic profile, the gels were previously scanned using the LabScam 5.0, this procedure was followed by the analysis in the Image Master Platinum program, 6.0 version (GE Healthcare), with the projection and smooth values equal to 100 and 2, respectively, making manual corrections. Three gels, were obtained with $70 \%$ of similarity to the selected breeder, at least. For this condition, the gel with the highest number of spots was considered the reference gel.

After the spots selection and trypsin digestion, the analysis for mass spectrometry (MS) was carried out in Ultraflex III MALDI TOF/TOF (Bruker Daltonics) spectrometer and in MALDITOF-TOF Autoflex spectrometer (Bruker Daltonics) spectrometer at Amazon Biotechnology Center (Centro 
de Biotecnologia da Amazônia) - CBA. The mass spectrum MS was analyzed to identify the protein based in the peptide mass fingerprint (PMF). First, it was used the Peak Erazor program (GPMAW) for the contaminants removal from the peaks list generated in Flex Analysis v3.3 program (Bruker Daltonics). Second, the new peaks list was analyzed in the Mascot program, PMF tool (Matrix Science) for comparing in the data bank. The selected parameters in Mascot PFM research were: NCBInr as data bank, trypsin enzyme, Mammalia as taxonomy, cysteine carbamidometilação as fixed modifications, methionine oxidation as variable modifications, mass values $\mathrm{MH}^{+}$ (monoloaded) and Peptidetol.土 1,2 from (Mascot - available at http://www.matrixscience.com/cgi/searc $\mathrm{h}$ form.pl?FORMVER $=2 \&$ SEARCH$=\mathrm{P}$ MF).

The distribution of the expression of the seminal plasma proteins was described (averages and dispersion measurements) using the Statview statistic program (version 5.0, SAS Institute Inc.2000).

\section{RESULTS AND DISCUSSION}

The parameters of the sheep fresh semen used in this work are described in the Table 1. Silva et al (2013) found similar values obtained in this study for: seminal volume $(1,63)$, aspect $(3,50)$ and turbulence $(4,33)$ in sheep Santa Ines in Manaus/AM property. Guimarães (2010) averaged $81,6 \%$ for motility and 3,6 for the vigor to evaluate the semen in natura breeding Santa Ines in the municipality of Castanhal/PA. Silva et al., (2008) observed motility of $81,43 \%$ and 3,76 vigor in breeding Santa Ines in the city of Araguaína/TO.
Table 1. Averages and their respective standard deviations to seven seminal characteristics, and scrotum perimeter evalueted in the semen of eight Santa Ines breed sheep in Manaus, AM, 2015

\begin{tabular}{lc}
\hline Seminal Characteristics & $\begin{array}{c}\text { Average } \pm \mathrm{sd} \\
(\mathrm{n}=08)\end{array}$ \\
\hline Spermatic Concentration & $5,8 \pm 0,4$ \\
$\left(\mathrm{x} 10^{9}\right.$ spermatozoons/mL) & $1,60 \pm 0,20$ \\
Volume (ml) & $3,50 \pm 1,05$ \\
Aspect (1-5) & $4,00 \pm 0,00$ \\
Turbulence $(0-5)$ & $87,00 \pm 2,44$ \\
Motility (\%) & $4,00 \pm 0,00$ \\
Vigor (0-5) & $5,00 \pm 0,00$ \\
Libido (0-5) & $30,04 \pm 1,49$ \\
Scrotum Perimeter $(\mathrm{cm})$ & \\
\hline
\end{tabular}

This shows that the values for the breed are approximate in different states of the North. Souza et al., (2007) found higher values for aspect $(4,5)$, turbulence $(4,77)$ and vigor $(4,59)$ and lower volume to $(1,48 \mathrm{ml})$ and motility $(84,47 \%)$ in Santa Ines sheep in Campo Maior/PI.

In the scrotum perimeter evaluation, the obtained value in this research corresponds to the averages described in the literature. The greatest interest by the value of the scrotal circumference, due to the possibility of estimating the relationship between the size and the function gametogênica (NOTTER et al., 1981) and thus predict the reproductive potential in sheep.

The average values of the spermatic pathology are presented in Table 2. The obtained averages to the spermatozoons morphological defects were inferior to the ones found by Silva et al. (2008) making the semen morphological evaluation of Santa Ines breeders in Tocantins State, as in head pathologies, intermediate part and tail, as in the biggest defects. These found higher values for the anomalies (4,28), 
intermediate $(0,57)$ and tail $(9,18)$ and major defects $(3,98)$ to the detriment to those obtained in this work.

Table 2. Averages and their respective standard deviations to six spermatozoons morphological characteristics of eight Santa Ines breed sheep in Manaus, AM, 2015

\begin{tabular}{lc}
\hline $\begin{array}{l}\text { Morphological } \\
\text { characteristics }\end{array}$ & Average $\pm \mathrm{sd}(\mathrm{n}=08)$ \\
\hline Head Defect & $0,40 \pm 0,37$ \\
Intermediate Part & $0,23 \pm 0,05$ \\
Defect & $4,08 \pm 0,73$ \\
Tail Defect & $3,16 \pm 0,43$ \\
Biggest Defects & $2,29 \pm 0,89$ \\
Smallest Defects & $5,45 \pm 0,63$ \\
\hline Total Defects & \\
\hline
\end{tabular}

In relation to the total defects, the obtained averages by the breeders were also inferior to the ones found by Maia et al. (2011) with values of 24,2 in sheep Santa Ines in Rio Grande do Norte, showing that the sheep had semen in better conditions than those of the studies cited, although the temperature be approximated. This may be related to other climatic factors (air humidity and photoperiod), as these affect the reproductive capacity of sheep.

108 spots were detected in a consistent form, according to the pairing generated by ImageMaster application version 6.0 based on gel master, which represents a combination between all spots present in the reference gel, beside the spots added from other gels, which were paired (Picture 1A). The intensity of these spots corresponded to a $82,3 \pm 0,74 \%$ of all spots intensity described in the main gel of the sheep semen plasma. Ten spots differences were submitted to the mass spectrometry (MALDI-ToF/ToF), which three were identified among them all (Picture 1B) and corresponded to three different proteins. Together, these spots represented $30,3 \pm 0,5 \%$ of all spots intensity detected in the two-dimensional maps.

The two-dimensional gel and the analysis by mass spectrometry showed the expression of the three proteins: Ram Seminal Vesicles Protein (RSVP) $22 \mathrm{kDa}$, clusterin and 14-3-3 zeta chain (Figure 1). RSVP-22, is a member of the BSPs superfamily and is secreted by the seminal vesicles, it was identified in only spot in the map 2-D of the sheep seminal plasma, showing the molecular mass of 60,7 $\mathrm{kDa}$ and $\mathrm{pI}$ de 4,2. The RSVPs act in the function of spermatozoons protection, preventing (PÉREZ-PÉ et al., 2001) and fixing (BARRIOS et al., 2000) damages to the spermatic membrane, caused during the cryopreservation process. Souza et al. (2012) identified the RSPVs as the major components of the gels of seminal plasma of sheep Santa Inês, constructed within the $\mathrm{pH}$ 4-7.

It was identified a spot relative to the clusterin protein. Souza et al., (2012), making a proteomic analysis of the reproductive trate of Santa Ines sheep, found two spots related to the clustrein. Moura et al. (2006b) reported that this protein is abundant in high fertility bulls. Clusterin may be expressed constitutively in the testicles, epididyms and prostate (SYLVESTER et al., 1991; SENSIBAR et al., 1993). Clustrein expression in the testicles and epididyms is an indicative that occurred a complete differenciation of the germinal cells (GRIMA et al., 1992; HERMO et al, 1992), suggesting that this protein might be involved with the spermatic maturation process (HERMO et al., 1991), spermatozoons protection (MERI et al., 2001), reabsorption of the defected spermatozoons in the epididym tail and modulation of the cell lysis (AKERLOF et al., 1989, MATSUOKA et al., 2006). 
Rev. Bras. Saúde Prod. Anim., Salvador, v.18, n.1, p.211-220 jan./mar., 2017
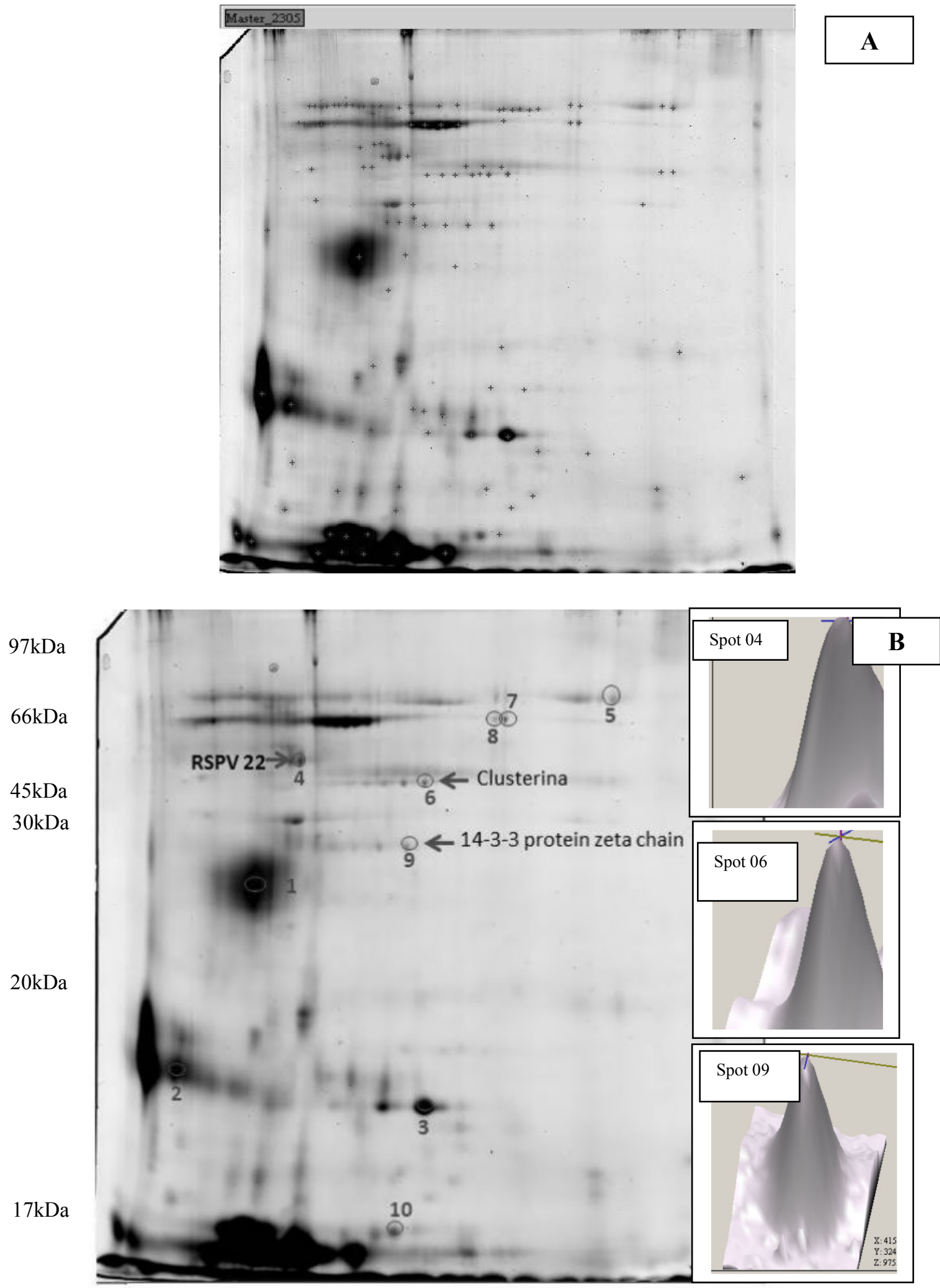

Figure 1. Santa Ines $\mathrm{n}^{\circ} 5$ sheep breeder two-dimensional map. A: Marked gels after spots detection by the Image Master Platinum program, 6.0 version (GE Healthcare). B: Selected spots to the mass spectrometry in MALDI-ToF/ToF and proteins identified by PMF tool (pepitide mass fingerprint) 
Another expressed protein in an only spot was the 14-3-3 zeta chain. Souza et al. (2012), analyzing the Santa Ines sheep seminal plasma in Ceara, it was also found a spot relative to that protein. The proteins family 14-3-3 zeta chain detected in Santa Ines seminal plasma is multifunctional and, supposedly involved in the signaling, traffic and cell accession (KJARLAND, 2006). They are intracellular proteins found in the bovine epididym sperm (HUANG et al., 2004), where they regulate the spermatic motility (SUN et al., 2009). The protein 14-3-3 zeta chain has an amino acid sequence highly preserved among the species (TZIVION \& AVRUCH, 2002). The 143-3 is located in the spermatozoon head rear region, acting in the protection and maintenance of the PP1 $\gamma 2$ phosphorylated, keeping low levels of the catalytic activity of this enzyme, an important required step to the maturation and startup of the spermatic motility during the epididym traffic (HUANG et al., 2004).

The identification of three protein in the semen plasma of Santa Ines sheep infer that semen plasma compounds of these animals take part in the physiological processes related to the spermatozoons protection, the motility and the spermatozoons capacity, all of them related to the fertility. The knowledge of these proteins contribute to a better comprehension of the semen plasma regulation mechanisms about the spermatic function in sheep.

\section{ACKNOWLEDGEMENTS}

To the Amazon State Support Research Foundation (FAPEAM) for financing, to the Amazon Biotechnology Center (CBA) the availability of laboratories, to the Amazon Rural Federal University (UFRA), the coordinator of PPGBAA, Reginaldo Alves Festucci Buselli and to the Amazon Federal University (UFAM) for assistance in research, and to the S. Pedro farm owner and sheepman, Igor Pedro, the availability of animals.

\section{REFERENCES}

AKERLÖF, E.; FREDRICSSON, B.; GUSTAFSON, O.; LUNELL, N.O.; NYLUND, L.; ROSENBORG, L.; SLOTTE, H.; POUSETTE, A. Serum factors stimulate the motility of human spermatozoa. International Journal of Andrology, v.12, p.124-130, 1989.

BARRIOS, B.; PÉREZ-PÉ, R.; GALLEGO, M.; TATO, A.; OSADA, J.; MUINO-BLANCO, T.; CEBRIÁNPÉREZ, J. A. Seminal plasma proteins revert the cold-shock damage on ram sperm membrane. Biology of Reproduction, v.63, p.1531-1537, 2000.

BELLIN, M.E.; OYARZO, J.N.; HAWKINS, H.E.; ZHANG, H.; SMITH, R.G.; FORREST, D.W.; SPROTT, L.R.; AX, R.L. Fertilityassociated antigen (FAA) on bull sperm indicates fertility potential. Journal of Animal Science, v.76, p.2032-2039, 1998.

CAVALCANTE, J.M.M.; AGUIAR, G.V.; SALMITO-VANDERLEY, C.S. Plasma seminal ovino e sua aplicação na biotecnologia reprodutiva. Revista Brasileira de Reprodução Animal, v.37, p.254-259, 2013.

\section{COLÉGIO BRASILEIRO DE REPRODUÇÃO ANIMAL - CBRA.} Manual para exame andrológico e avaliação de sêmen animal. 2.ed. Belo Horizonte, 1998. 49p. 
GRIMA, J.; PINEAU, C.; BARDIN, C.W.; CHENG, C.Y. Rat Sertoli cell clusterin, alpha 2-macroglobulin, and testins: biosynthesis and differential regulation by germ cells. Molecular and Cellular Endocrinology, v.89, p.127-140, 1992.

\section{GUIMARÃeS, A.A. Avaliação de} diferentes diluentes na criopreservação de sêmen ovino (Ovis aries). 2010. 76f. Dissertação (Mestrado em Ciência Animal) Universidade Federal do Pará, Belém.

HERMO, L.; BARIN, K.; ROBAIRE, B. Structural differentiation of the epithelial cells of the testicular excurrent duct system of rats during postnatal development. The

Anatomical Record, v.233, p.205-228, 1992.

HERMO, L.; WRIGHT, J.; OKO, R.; MORALES, C.R. Role of epithelial cells of the male excurrent duct system of the rat in the endocytosis or secretion of sulfated glycoprotein-2 (clusterin).

Biology of Reproduction, v.44, p.1113-1131, 1991.

HEYER, L. F. Manaus: um exemplo de clima urbano em região subequatorial. 1997. 198p. Tese (Doutorado em Geografia) - Universidade de São Paulo, São Paulo.

HUANG, Z.; MYERS, K.; KHATRA, B.; VIJAYARAGHAVAN, S. Protein 14-3-3 binds to protein phosphatase PP $1 \gamma 2$ in bovine epididymal spermatozoa. Biology of

Reproduction, v.71, p.177-84, 2004.

INSTITUTO NACIONAL DE METEOROLOGIA - INMET. Previsão do tempo. 2006.
JOBIM, M.I.M.; GREGORY, R.M.; MATTOS, R.C. Marcadores proteicos de fertilidade no plasma seminal e na membrana plasmática. In:

CONGRESSO BRASILEIRO DE REPRODUÇÃO ANIMAL, 18, 2009, Belo Horizonte. Anais... Belo Horizonte: CBRA, 2009. p.15-23.

KILLIAN, G.J; CHAPMAN, D.A.; ROGOWSKI, L.A. Fertility-associated proteins in Holstein bull seminal plasma. Biology of Reproduction, v.49, p.1202-1207, 1993.

KILLIAN, G. J; CHAPMAN, D. A.; ROGOWSKI, L. A. Fertility-associated proteins in Holstein bull seminal plasma. Biol Reprod, v.49, p.12021207, 1993.

KJARLAND, E.; KEEN, T.J.; KLEPPE, R. Does isoform diversity explain functional differences in the 143-3 protein family? Curr Pharm Biotechnol, v.7, p.217-23, 2006.

MAIA, M.S.; MEDEIROS, I.M.; LIMA, C.A.C. Características reprodutivas de carneiros no Nordeste do Brasil: parâmetros seminais. Revista Brasileira de Reprodução Animal, v.35, n.2, p.175-179, 2011.

MATSUOKA, T.; IMAI, H.; KOHNO, H.; FUKUI, Y. Effects of bovine serum albumin and trehalose in semen diluents for improvement of frozen-thawed ram spermatozoa. Journal of Reproduction and Development, v.52, p.675-683, 2006.

MERI, S., JARVA, H. Complement regulatory proteins. Nature Encyclopedia of Life Sciences, p.1-7, 2001. 
MOURA, A.A.; CHAPMAN, D.A.; KOC, H.; KILLIAN, G.J. A comprehensive proteomic analysis of the accessory sex gland fluid from mature Holstein bulls. Animal

Reproduction Science, v.98, p.169-88, 2007.

MOURA, A.A.; CHAPMAM, D.A.; KILLIAN, G.J. Proteins of the cauda epididymal fluid associated with fertility of mature dairy bulls. Journal of Andrology, v.27, p.534-41, 2006a.

MOURA, A.A.; KOC, H.; CHAPMAN, D.A.; KILLIAN, G.J. Identification of proteins in the accessory sex gland fluid associated with fertility indexes of dairy bulls: a proteomic approach. Journal of Andrology, v.27, p.201-211, 2006b.

NOTTER, D.R.; LUCAS, J.R.; McCLAUGHERTY, F.S. Accuracy or estimation of testis weight from in situ testis measures in ram lambs.

Theriogenology, v.15, n.3, p.227-234, 1981.

PACHECO, A.; MADELLA

OLIVEIRA, A.F.; QUIRINO, C.R.;

LANDIN, A.V. Características seminais de carneiros da raça Santa Inês na prépuberdade, puberdade e na pós-

puberdade. ARS Veterinária, v.25, p.9099, 2009.

PÉREZ-PÉ, R.; CEBRIÁN-PÉREZ, J.A.; MUIÑO-BLANCO, T. Semen plasma proteins prevent cold-shock membrane damage to ram spermatozoa.

Theriogenology, v.56, p.425-434, 2001.

REGO, J.P.A.do. Análise proteômica do plasma seminal de carneiros Santa Inês adultos. 2010. 110. Dissertação (Mestrado) - Universidade Federal do Ceará, Fortaleza.
SENSIBAR, J.A.; QIAN, Y.; GRISWOLD, M.D.; SYLVESTER, S.R.; BARDIN, C.W.; CHENG, C.Y.; LEE, C. Localization and molecular heterogeneity of sulfated glycoprotein-2 (clusterin) among ventral prostate, seminal vesicle, testis and epididymis of rats. Biology of Reproduction, v.49, p.233-242, 1993.

SILVA, A.F.; OLIVEIRA, R.P.M.; OLIVEIRA, M.A. Avaliação da Biometria testicular, parâmetros seminais e comportamento sexual de ovinos Santa Inês, Dorper e White Dorper no Amazonas. In: CONGRESSO BRASILEIRO DE REPRODUÇÃO ANIMAL, 20., 2013, Uberlândia. Anais... Minas Gerais: Universidade Federal de Uberlândia, 2013.

SILVA, L.M.; SILVA, C.M.G.; CAVALCANTE, T.V. Utilização do Corante Rosa Bengala no Método de Preparação Úmida para Avaliação Morfológica de Sêmen Ovino. Revista Científica de Produção Animal, v.10, n.2, p.174-180, 2008.

SOUZA, C.E.A.; REGO, J.P.A.; LOBO, C.H.; OLIVEIRA, J.T.A.; NOGUEIRA, F.S.; DOMONT, G.B.; MOURA, A.A. Proteomic analysis of the reproductive tract fluids from tropically-adapted Santa Ines rams. Journal of Proteomics, v.75, v.14, p.4436-56, 2012.

SOUZA, J.A.T.; CAMPELO, J.E.G.; MACEDO, N.A.; LEAL, T.M.; SOUSA JÚNIOR, A.; MEDEIROS, R.M.; CHAVES, R.M. Biometria testicular, características seminais, libido e concentração de testosterona em ovinos da raça Santa Inês, criados a campo, na microrregião de Campo Maior, Piauí. Ciência Veterinária nos Trópicos, v.10, p.21-28. 2007. 
SPROTT, L.R.; HARRIS, M.D.;

FORREST, D.W.; YOUNG, J.;

ZHANG, H.M.; OYARZO, J.N.;

BELLIN, M.E.; AX, R.L. Artificial

insemination outcomes in beef females using bovine sperm with a detectable fertility-associated antigen. Journal of Animal Science, v.78, p.795-798. 2000.

SUN, S.; WONG, E.W.P.; LI, M.W.M.; LEE, W.M.; CHENG, C.Y. 14-3-3 and its binding partners are regulators of protein-protein interactions during spermatogenesis. Journal of

Endocrinology, v.202, p.327-36, 2009.

SYLVESTER, S.R.; MORALES, C.; OKO, R.; GRISWOLD, M.D.

Localization of sulfated glycoprotein-2 (clusterin) on spermatozoa and in the reproductive tract of the male rat.

Biology of Reproduction, v.31, p.1087-1101, 1991.

TZIVION, G.; AVRUCH, J. 14-3-3 proteins: active cofactors in cellular regulation by serine/threonine phosphorylation. Journal of Biological Chemistry, v.277, p.3061-3064, 2002.

VALLE, R.V. Variação sazonal das proteínas do plasma seminal de caprinos (Capra hircus) da raça moxotó. 2012. 75f. Dissertação

(Mestrado) - Universidade Estadual do Vale do Acaraú, Sobral.

Data de recebimento: 23/05/2016

Data de aprovação: 06/10/2016 